\title{
Holohemispheric developmental venous anomaly
}

Figure MRI of holohemispheric developmental venous anomaly

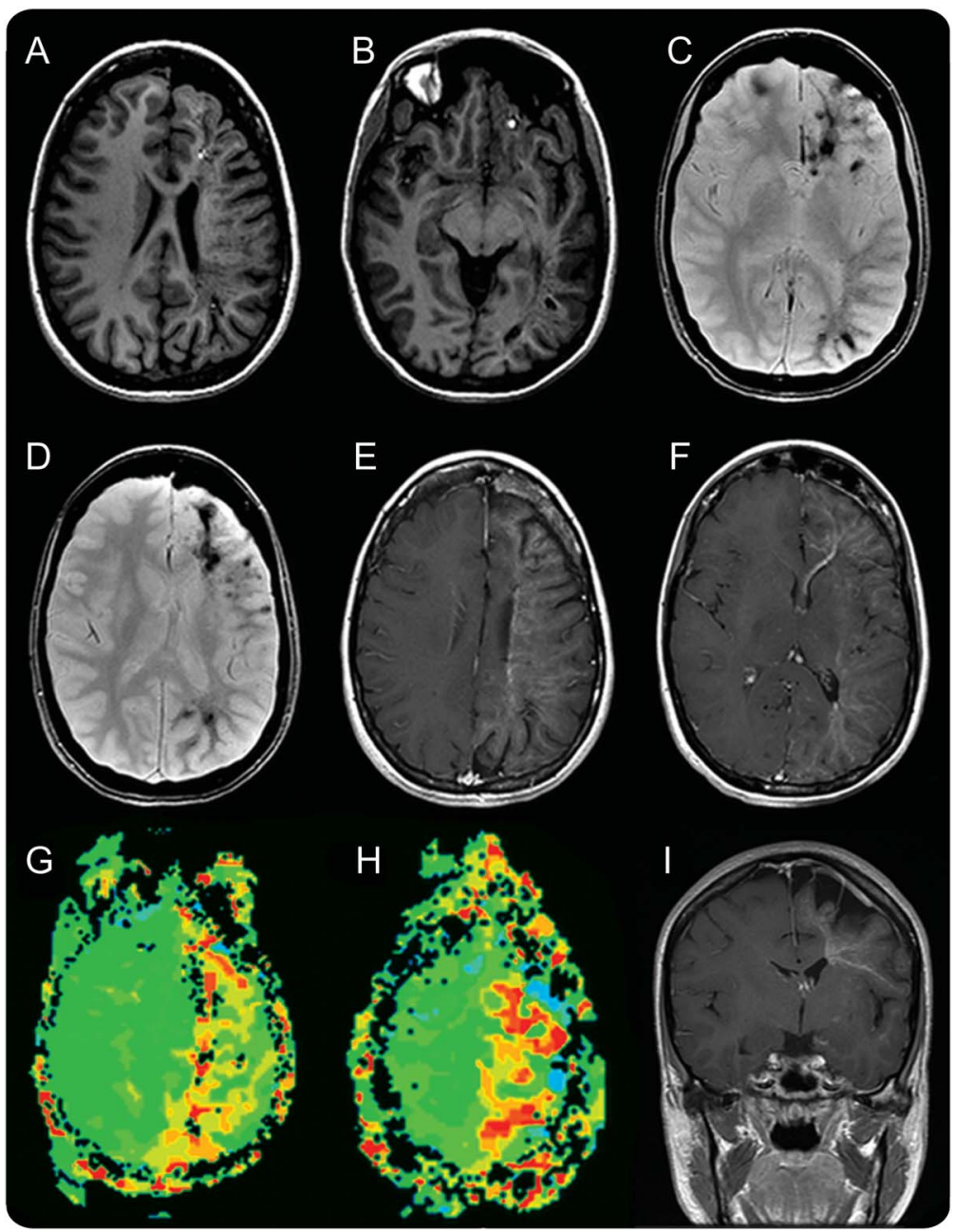

(A, B) Precontrast axial T1-weighted images. (C, D) Axial T2* gradient echo. (E, F) Postcontrast axial T1 spin echo. (G, H) Axial time to minimum perfusion map. (I) Postcontrast axial gradient echo T1 coronal.

Developmental venous anomalies (DVA) are normally diminutive and incidental. ${ }^{1,2}$ In this 33 -year-old patient with epilepsy, the DVA is holohemispheric. Her epilepsy probably originates from the left side based on semiology; the EEG displayed left-sided slowing. Axial T1-weighted sequences show skull atrophy, ventricular widening, and satellite cavernous malformations with accumulation of subacute blood products including hemosiderin (figure, A and B). T2 gradient echo illustrates pockets of chronic hemorrhage (figure, C and D). Engorged holohemispheric anomalous venous structures channel into ventricular periependymal veins, illustrated by mulitplanar T1 echo spin postcontrast sequences (figure, E and F). Time to minimum perfusion reflects elevated transit times, suggesting venous hypertension and capillary backpressures.

Andrew K. Jung, John W. Henson, MD, Daniel Susanto, MD, Lisa M. Caylor, MD, Michael J. Doherty, MD

From the Zanvyl Krieger School of Arts and Sciences (A.K.J.), Johns Hopkins University, Baltimore, MD; and Swedish Neuroscience Institute (J.W.H., D.S., L.M.C., M.J.D.), Seattle, WA. 
Author contributions: A.K. Jung: drafting of manuscript, data collection. Dr. Henson: data collection, imaging review. Dr. Susanto: drafting of manuscript, imaging review. Dr. Caylor: drafting of manuscript, data collection. Dr. Doherty: manuscript coordination and drafting.

Study funding: No targeted funding reported.

Disclosure: The authors report no disclosures relevant to the manuscript. Go to Neurology.org for full disclosures.

Correspondence to Dr. Doherty: Michael.doherty@swedish.org

1. Aagaard BD, Song JK, Eskridge JM, Mayberg MR. Complex right hemisphere developmental venous anomaly associated with multiple facial hemangiomas. J Neurosurg 1999;90:766-769.

2. Casey MA, Lahoti S, Gordhan A. Pediatric holohemispheric developmental venous anomaly: definitive characterization by 3D susceptibility weighted magnetic resonance angiography. J Radiol Case Rep 2011;5:10-18.

\section{NeuroImages Are Free at www.neurology.org!}

All Neurology ${ }^{\circledR}$ NeuroImages can now be freely accessed on the Neurology Web site. See them at www.neurology.org, where you can also sign up for journal email alerts and check out other online features, including the Resident \& Fellow section, Neurology: Clinical Practice, and the weekly Neurology Podcasts. 


\title{
Neurology
}

\author{
Holohemispheric developmental venous anomaly \\ Andrew K. Jung, John W. Henson, Daniel Susanto, et al. \\ Neurology 2013;80;1718-1719 \\ DOI 10.1212/WNL.0b013e3182904fbb
}

This information is current as of April 29, 2013

\section{Updated Information \& Services}

\section{References}

Subspecialty Collections

Permissions \& Licensing

Reprints including high resolution figures, can be found at: http://n.neurology.org/content/80/18/1718.full

This article cites 2 articles, 0 of which you can access for free at: http://n.neurology.org/content/80/18/1718.full\#ref-list-1

This article, along with others on similar topics, appears in the following collection(s):

All Epilepsy/Seizures

http://n.neurology.org/cgi/collection/all_epilepsy_seizures MRI

http://n.neurology.org/cgi/collection/mri

Other cerebrovascular disease/ Stroke

http://n.neurology.org/cgi/collection/other_cerebrovascular_disease_st roke

Information about reproducing this article in parts (figures,tables) or in its entirety can be found online at:

http://www.neurology.org/about/about_the_journal\#permissions

Information about ordering reprints can be found online:

http://n.neurology.org/subscribers/advertise

Neurology ${ }^{\circledR}$ is the official journal of the American Academy of Neurology. Published continuously since 1951, it is now a weekly with 48 issues per year. Copyright @ 2013 American Academy of Neurology. All rights reserved. Print ISSN: 0028-3878. Online ISSN: 1526-632X.

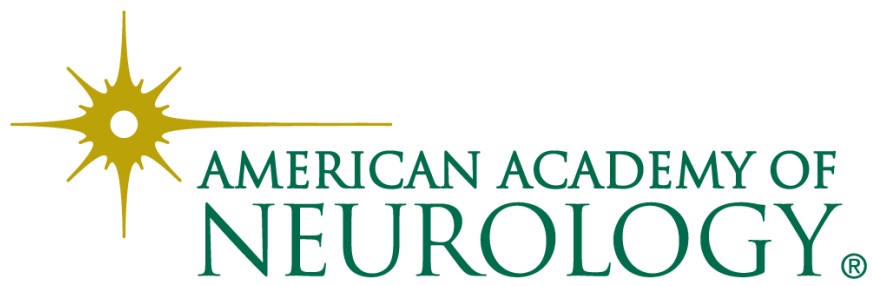

